\title{
ASSESSING SUSTAINABILITY LEVEL FROM SOCIAL ASPECTS FOR AFFORDABLE HOUSING IN MALAYSIA USING SPATIAL INDICATORS
}

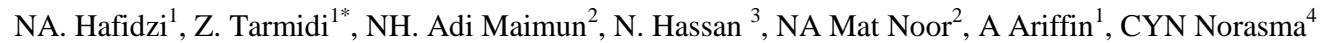 \\ ${ }^{1}$ Geoinformation, Faculty of Built Environment and Surveying, Universiti Teknologi Malaysia, 81310 UTM Johor Bahru, Johor - \\ nazminamalina@gmail.com, zakritarmidi@utm.my, azmanariffin@utm.my \\ ${ }^{2}$ Centre for Real Estate Studies, Institute for Smart Infrastructure and Innovative Construction, Faculty of Built Environment and \\ Surveying, Universiti Teknologi Malaysia, 81310 UTM Johor Bahru, Johor - nurulhana@utm.my, noorsidi@utm.my \\ ${ }^{3}$ INSTEG, Faculty of Built Environment and Surveying, Universiti Teknologi Malaysia, 81310 UTM Johor Bahru, Johor - \\ noordyana@utm.my \\ ${ }^{4}$ Department of Agriculture Technology, Faculty of Agriculture, Universiti Putra Malaysia, Malaysia - niknorasma@upm.edu.my
}

KEY WORDS: Affordable housing, sustainability, social aspects, spatial indicators

\begin{abstract}
:
Affordable housing was developed in order to give equal opportunity for middle and low-incomers in owning a house, especially in Malaysia. To make sure that these people can have a quality house, the National Housing Policy (DRN) with Pelan Tindakan DRN has been introduced by the Malaysian Government to not only provide adequate housing, but also a comfortable, fun and affordable for the wellbeing of the people in Malaysia (KPKT, 2011). Therefore, sustainability for housing is important to achieve balance between economic development, social interactions and environmental impact by reducing the problems related to population growth, urbanisation, slums, poverty, climate change, lack of access to sustainable energy, and economic uncertainty. One of the goals in DRN and Pelan Tindakan Dasar Perumahan Negara (PTDRN) is to provide an affordable housing and ensure the people from low-income can own a house. However, there is an issue towards assessing the sustainability level of affordable housing, especially in social aspects. This study will discuss on sustainability of affordable housing in Malaysia focused on social aspects. Assessment of spatial indicators was conducted to assess the indicator's implementation of social aspect of the sustainability model. The indicators used in this study include public community facilities, health, safety, religion, and public transportation. These indicators will determine the level of sustainability of the affordable housing. From the results, most of the affordable housing in Malaysia is in intermediate level of sustainability in term of social aspects. These results can help/guide the Government in planning and development in the future, especially with collaboration from private agencies and non-government organization (NGO).
\end{abstract}

\section{INTRODUCTION}

\subsection{Background Study}

Housing is a basic requirement that can enhance the quality of one's life. To make sure the people own a quality home, the National Housing Policy (DRN) was introduced by the Malaysian Government in providing adequate housing, comfortable, fun and affordable for the wellbeing of Malaysians (KPKT, 2011). To achieve the goal of DRN, the National Housing Department (JPN, KPKT) Malaysia produced Pelan Tindakan Dasar Perumahan Negara in 2012. The plans provide guidelines that are consistent with strategic goals and core of DRN (KPKT, 2012).

In Malaysia, affordable housing was developed, so that middle and low-incomers were given equal opportunity in owning a house. Generally, affordable housing in Malaysia were made affordable for household income, ranging from RM2, 500 to RM3, 999 (KPKT, 2011). As years goes by, affordable housing in Malaysia have improved and were introduced in 7th Malaysia Plan (RMK7) (7th Malaysia Plan, 1996 - 2000). The affordable housing was grouped into four (4) categories; low cost, low-medium cost, medium cost, and high cost housing (Tan, 2011). In 2017, Syarikat Perumahan Negara Berhad (SPNB) proposed and classified the affordable housing into low cost, low-medium cost, and medium cost housing. Moreover, the houses were priced differently in Peninsular Malaysia, Sabah and Sarawak.
There are several affordable housing launched by the Ministry of Housing and Local Government (KPKT), State Government and private developers. For examples, 1Malaysia People's Housing Programme (PR1MA), 1Malaysia Civil Servant Housing Programme (PPA1M), Rumah Mesra Rakyat 1Malaysia (RMR1M), People's Housing Project (PPR), MyHome, Federal Territory Affordable Housing Policy (RUMAWIP) and etc (Nurshuhada Zainon et al, 2017).

One aspect of housing that has been listed in DRN is housing sustainability. Sustainability in housing is important in order to give an economic development that can reduce the problems related to population growth, urbanisation, slums, poverty, climate change, lack of access to sustainable energy, and economic uncertainty (Golubchikov \& Badyina, 2012). To achieve e sustainability, developers are urged to study the guideline and practice with what has been outline by KPKT. Generally, there are three (3) aspects in sustainability development; economic, environmental and social. These three (3) aspects must be in balanced in order to achieve sustainability level of housing. Hence, development of sustainable surrounding in affordable housing area can influence a sustainable way of living within a community.

To achieve sustainability level in affordable housing development in Malaysia, several criteria need to be identified. For instance, $\mathrm{t}$ initiatives made from different countries in implementing sustainable housing. In Malaysia, the criteria, 
which was to assess a sustainable housing development are listed as one of the thrust in DRN and Pelan Tindakan Dasar Perumahan Negara (KPKT, 2012). Besides that, Malaysian government also introduced Malaysian Urban Indicator Network (MurniNet) indicators for assessing sustainability of urban development. The MurniNet is a method which measures the level of sustainable area that is capable of sustaining its social, economic and physical development whilst maintaining its excellence in culture and environment.

Other than DRN and MurniNet, Indeks Kesejahteraan Keluarga Malaysia (IKKM) is also one of the indicators that can measure sustainability level of housing in Malaysia, focusing on social and economic aspects. IKKM measures the sustainability of the housing based on the assessment towards the level of family well-being. It consists of domain, focusing the indicator of economic and social aspects of sustainability. To assess the sustainability of social aspects, there's a need to study the indicators related to social aspect. This study aim is to assess sustainability level of affordable housing from social aspect, using spatial indicators. To achieve this, three (3) objectives was listed; (1) to identify the spatial indicators of sustainability from social aspect for affordable housing, (2) to analyse the sustainability level from social aspect for affordable housing by using spatial indicators, and (3) to assess the sustainability level for affordable housing by using social aspects indicators.

\section{METHODOLOGY}

In order to assess the sustainability level of affordable housing from social aspect, this study uses Multi-Criteria Decision Making (MCDM): Analytical Hierarchy Process (AHP). Figure 1 shows the study approach on how this research is being performed. Several steps needed to accomplish this study.

\subsection{Identifying Spatial Indicators}

The first step is to identify the spatial indicators that are related to sustainability level in term of social aspects. To identify these indicators, review from various models from previous studies was conducted. For instance, Sustainable Development Goals (SDG) model from United Nation, MurniNet 2.0, Indeks Kesejahteraan Keluarga Malaysia (IKKM), National Housing Policy (DRN), and other related model. From these models, a list of indicators that are related to social aspects was listed and reviewed. From the reviewing process, 5 main indicators and 10 sub-indicators was selected in in this study (Table 1).

\begin{tabular}{|l|l|l|}
\hline Indicator & Sub-Indicator & Source \\
\hline Public & Community Hall, Town & DRN, \\
community & $\begin{array}{l}\text { Hall, Public Hall, }, \\
\text { Multipurpose Hall }\end{array}$ & $\begin{array}{l}\text { PTDR, } \\
\text { MurniNet }\end{array}$ \\
\hline $\begin{array}{l}\text { Public } \\
\text { Transportation }\end{array}$ & $\begin{array}{l}\text { Train station, bus } \\
\text { terminal }\end{array}$ & $\begin{array}{l}\text { DRN, } \\
\text { PTDRN }\end{array}$ \\
\hline Religion & Mosque (surau, & IKKM \\
\hline Safety & Police station & MurniNet \\
\hline Health & Hospital, Clinic & MurniNet \\
\hline
\end{tabular}

Table 1: The indicators and sub-indicator of social aspect

*Notes:

DRN: Dasar Perumahan Negara

PTDRN: Pelan Tindakan DRN

MurniNet: Theme in MurniNet 2.0

IKKM: Indeks Kesejahteraan Keluarga Malaysia

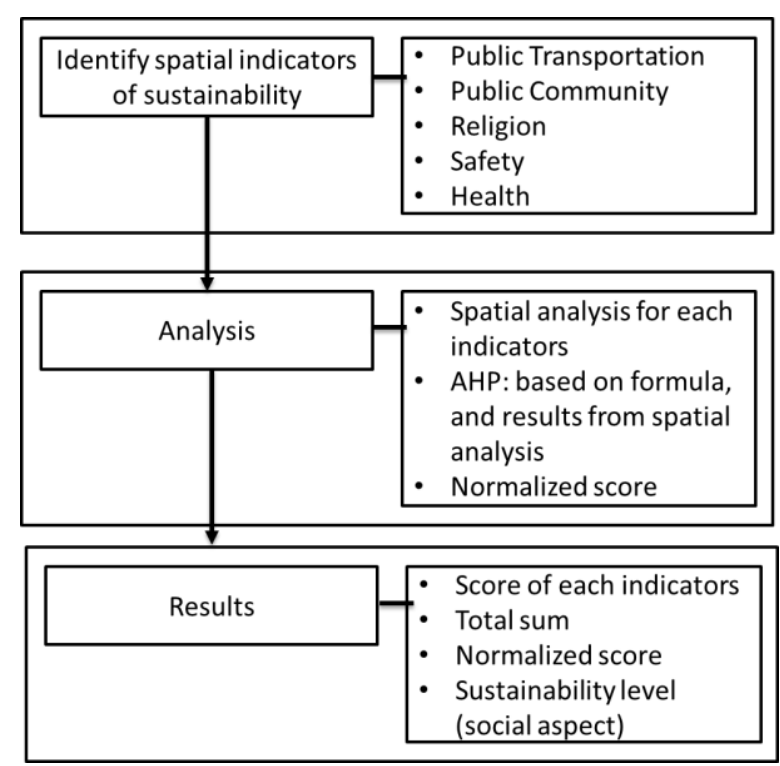

Figure 1: Study Approach

\subsection{Analysis}

The second step is analysis. In this step, spatial analysis has been done from the list of sub-indicators. The spatial analysis conducted in this study aim to enhance the current model in assessing the sustainability level of the affordable housing from social aspects. The analysis will determine the sustainability level according to the guideline provided by Jabatan Perancangan Bandar dan Desa (JPBD) towards the radius distance accessibility between residential housing and location of public facilities that are related to social aspect. Table 2 until Table 6 shows the radius distance accessibility between residential housing and social indicator used in this study. From this lists, spatial analysis was made to identify the score for each affordable housing.

\begin{tabular}{|l|l|l|}
\hline Indicator & Accessibility Distance & Score \\
\hline \multirow{2}{*}{$\begin{array}{l}\text { Community } \\
\text { Balai Raya })\end{array}$} & $0-400 \mathrm{~m}$ & 3 \\
\cline { 2 - 3 } & $401 \mathrm{~m}-800 \mathrm{~m}$ & 2 \\
\cline { 2 - 3 } & $>800 \mathrm{~m}$ & 1 \\
\hline Public Hall (Dewan & $0-800 \mathrm{~m}$ & 2 \\
\cline { 2 - 3 } $\begin{array}{l}\text { Orang Ramai) } \\
\text { Multipurpose Hall } \\
\text { (Dewan Serbaguna) }\end{array}$ & $0-1000 \mathrm{~m}$ & 1 \\
\cline { 2 - 3 } & $>1000 \mathrm{~m}$ & 2 \\
\hline
\end{tabular}

Table 2: The radius distance accessibility between residential housing and public community facilities indicator

\begin{tabular}{|l|l|l|}
\hline Indicator & Accessibility Distance & Score \\
\hline \multirow{3}{*}{ Train Station } & $0-400 \mathrm{~m}$ & 3 \\
\cline { 2 - 3 } & $401 \mathrm{~m}-800 \mathrm{~m}$ & 2 \\
\cline { 2 - 3 } & $>800 \mathrm{~m}$ & 1 \\
\hline \multirow{3}{*}{ Bus Terminal } & $0-400 \mathrm{~m}$ & 3 \\
\cline { 2 - 3 } & $401 \mathrm{~m}-800 \mathrm{~m}$ & 2 \\
\cline { 2 - 3 } & $>800 \mathrm{~m}$ & 1 \\
\hline
\end{tabular}

Table 3: The radius distance accessibility between residential housing and public transportation indicator

\begin{tabular}{|l|l|l|}
\hline Indicator & Accessibility Distance & Score \\
\hline \multirow{2}{*}{ Mosque } & $0-800 \mathrm{~m}$ & 2 \\
\cline { 2 - 3 } & $>800 \mathrm{~m}$ & 1 \\
\hline \multirow{2}{*}{ Surau } & $0-400 \mathrm{~m}$ & 3 \\
\cline { 2 - 3 } & $401 \mathrm{~m}-800 \mathrm{~m}$ & 2 \\
\hline
\end{tabular}




\begin{tabular}{|c|c|c|}
\hline & $>800 \mathrm{~m}$ & 1 \\
\hline \multicolumn{3}{|c|}{$\begin{array}{c}\text { Table 4: The radius distance accessibility between residential } \\
\text { housing and religion indicator }\end{array}$} \\
\hline Indicator & Accessibility Distance & Score \\
\hline \multirow{4}{*}{ Hospital } & $0-25 \mathrm{~km}$ & 4 \\
\hline & $26 \mathrm{~km}-50 \mathrm{~km}$ & 3 \\
\hline & $51 \mathrm{~km}-75 \mathrm{~km}$ & 2 \\
\hline & $76 \mathrm{~km}-100 \mathrm{~km}$ & 1 \\
\hline \multirow[t]{2}{*}{ Clinic } & $0-800 \mathrm{~m}$ & 2 \\
\hline & $>800 \mathrm{~m}$ & 1 \\
\hline
\end{tabular}

Table 5: The radius distance accessibility between residential housing and health indicator

\begin{tabular}{|l|l|l|}
\hline Indicator & Accessibility Distance & Score \\
\hline Police Station & $0-800 \mathrm{~m}$ & 2 \\
\cline { 2 - 3 } & $>800 \mathrm{~m}$ & 1 \\
\hline
\end{tabular}

Table 6: The radius distance accessibility between residential housing and safety indicator

The score for each accessibility distance indicates that with a higher value, the more sustainable the residential housing is. To assess the sustainability, Analytic Hierarchy Process (AHP) is use to determine the sustainability level for each of the social indicator. AHP is one of famous method in Multi-Criteria Decision Making (MCDM). The AHP procedure had been applied for Decision Support System (DSS), including data mining, machine learning and so many applications. To gain the results of the sustainability level, the location of the house will buffer based on the accessibility distance. Then, the score will be obtained from the buffer analysis.

The formula used to compute the sustainability level is the Cross Tabulation and Evaluation based on Rank. Cross Tabulation is the simplest multi criteria decision making that put criteria and alternatives into a cross table. Then, the score value is keyed in for each cell of the table. The sum (or normalized sum) of all factors for each alternatives are computed. This results was then normalized. The formula of normalization was used to normalize the score in order to achieve the rank for the social indicator. The formula of the normalization would be:

\section{Normalized score $=$ Sum $/$ Total Sum $* 100$}

After the score has been normalized, the sustainability level (\%) was calculated with the formula below: $\begin{aligned} \text { Sustainability Level }(\%)= & \text { Normalized score/ Total Max Score } \\ & * 100\end{aligned}$

\subsection{Results}

Results from various spatial analysis was combine, as well as the final score, which includes all the score listed (Table 7).

\section{RESULTS AND DISCUSSIONS}

The results from the analysis are according to the social aspects, that is public community facilities, health, safety, religion, and public transportation.. Table 7 shows the results of the indicators and alternatives with scores obtained from the analysis.

From Table 7, in term of Public Community's indicators, 4 out of 12 affordable housing scored 2 and 3 for sub-indicators; Balai Raya (Community Hall), and 8 of the affordable housing don't have Balai Raya. In term of Dewan Orang Ramai (Public Hall), only one affordable housing scored 2, and the others scored 1. For Dewan Serbaguna (Multipurpose Hall), 5 affordable housing scored 2 , and 7 affordable housing scored 1 .

For health indicators, 2 main sub-indicators were assessed, which are the distance of the affordable housing to the hospital, and distance to the government clinic. From the analysis, all of the affordable housing scored (4), which is the highest score, because most of the affordable housing is less than $25 \mathrm{~km}$ from hospital. However, in terms of distance to the government clinic, only 2 affordable housing scored 2, which is less than $800 \mathrm{~m}$ from the government clinic.

For religion indicators, 2 sub-indicators was assessed, which is distance to the mosque (masjid), and surau. The score for both sub-indicators is vary, combining between 1 to 3 , but most of the affordable housing scored 1, and only 3 affordable housing is near the mosque (distance less than $800 \mathrm{~m}$ ), and for surau, 2 affordable housing scored 3 (distance less than 400m), and 3 affordable housing scored 2 (distance between $400 \mathrm{~m}$ to $800 \mathrm{~m}$ ).

For safety indicators, all of the affordable housing only scored 1 , which conclude that all the affordable housing is far from the police station (distance more than $800 \mathrm{~m}$ ).

The last indicators are public transportation. The sub-indicators are distance to the train station, and distance to the bus terminal. From analysis, only 1 affordable housing is near to the train station (distance between $400 \mathrm{~m}$ to $800 \mathrm{~m}$ ), but all of the affordable housing in this study is far away from the bus terminal (distance more than $800 \mathrm{~m}$ ).

From analysis, the combination score then was conclude, where the maximum total score is 26. From analysis, all of the affordable housing score is more than half (more than 13). However, the score did not show the actual level of sustainability, due to different maximum score for each subindicator. To normalize the score, AHP technique was used, with combination of Cross tabulation and Evaluation Based on Rank. From the final calculation, the sustainability level for all of the affordable housing is less than 50\% (Table 7). 


\begin{tabular}{|c|c|c|c|c|c|c|c|c|c|c|c|c|c|}
\hline \multirow{3}{*}{ House Name } & \multicolumn{10}{|c|}{ Score } & \multirow{3}{*}{ Total } & \multirow{3}{*}{$\begin{array}{l}\text { Norm. } \\
\text { Score }\end{array}$} & \multirow{3}{*}{$\begin{array}{c}\text { Sust. } \\
\text { Level } \\
(\%)\end{array}$} \\
\hline & \multicolumn{3}{|c|}{$\begin{array}{c}\text { Public } \\
\text { Community }\end{array}$} & \multicolumn{2}{|c|}{ Health } & \multicolumn{2}{|c|}{ Religion } & \multirow{2}{*}{$\begin{array}{c}\text { Safety } \\
\text { PS }\end{array}$} & \multicolumn{2}{|c|}{$\begin{array}{c}\text { Public } \\
\text { Transportation }\end{array}$} & & & \\
\hline & BR & DOR & DS & $\mathbf{H}$ & $\mathbf{C l}$ & $\mathbf{M}$ & $\mathbf{S}$ & & TS & BT & & & \\
\hline Palma Apartment & 3 & 1 & 1 & 4 & 1 & 1 & 2 & 1 & 1 & 1 & 16 & 8.79 & 33.81 \\
\hline Pangsapuri Taman Setia & 1 & 1 & 2 & 4 & 1 & 2 & 1 & 1 & 1 & 1 & 15 & 8.24 & 31.70 \\
\hline Apartment Selayang Mulia & 1 & 1 & 2 & 4 & 1 & 1 & 1 & 1 & 1 & 1 & 14 & 7.69 & 29.59 \\
\hline Pangsapuri Cempaka & 2 & 1 & 2 & 4 & 1 & 1 & 2 & 1 & 1 & 1 & 16 & 8.79 & 33.81 \\
\hline Pangsapuri Laksamana Jaya & 2 & 2 & 2 & 4 & 2 & 2 & 2 & 1 & 1 & 1 & 19 & 10.44 & 40.15 \\
\hline Pangsapuri Ria & 3 & 1 & 1 & 4 & 2 & 1 & 3 & 1 & 2 & 1 & 19 & 10.44 & 40.15 \\
\hline Fiona Apartment & 1 & 1 & 1 & 4 & 1 & 1 & 1 & 1 & 1 & 1 & 13 & 7.14 & 27.47 \\
\hline PPR Gombak Setia & 1 & 1 & 1 & 4 & 1 & 1 & 1 & 1 & 1 & 1 & 13 & 7.14 & 27.47 \\
\hline Pangsapuri Taman Samudera & 1 & 1 & 1 & 4 & 1 & 1 & 1 & 1 & 1 & 1 & 13 & 7.14 & 27.47 \\
\hline PR1MA Kajang Utama & 1 & 1 & 1 & 4 & 1 & 1 & 1 & 1 & 1 & 1 & 13 & 7.14 & 27.47 \\
\hline $\begin{array}{l}\text { PR1MA Bandar Bukit } \\
\text { Mahkota }\end{array}$ & 1 & 1 & 1 & 4 & 1 & 1 & 3 & 1 & 1 & 1 & 15 & 8.24 & 31.70 \\
\hline PPR Hiliran Ampang & 1 & 1 & 2 & 4 & 1 & 2 & 2 & 1 & 1 & 1 & 16 & 8.79 & 33.81 \\
\hline Total Score & & & & & & & & & & & 182 & & \\
\hline Total Max Score & 3 & 2 & 2 & 4 & 2 & 2 & 3 & 2 & 3 & 3 & 26 & & \\
\hline
\end{tabular}

Table 7: The scores obtained for indicators and alternatives

*Notes:

BR: Balai Raya

DOR: Dewan Orang Ramai

DS: Dewan Serbaguna

H: Hospital

$\mathrm{Cl}$ : Clinic

M: Mosque

S: Surau

PS: Police Station

TS: Train Station

BT: Bus Terminal

\subsection{Findings}

Based on Table 7 and Figure 1, the results indicates that all the affordable housing in twelve (12) locations in Selangor has low level of sustainability in term of social aspects, where the results presents all the scores is below 50 percent (\%).

The score for Public Community is low for most of the housing, for BR, where only 2 housing scored 3, 2 housing scored 2, and other scored 1 . For DOR, only 1 housing scored 2, and the other scored 1. For DS, 5 housing scored 2, and the other scored 1.

For Health indicators, for Hospital, all of the housing scored highest (4), but for clinic, only 2 housing scored 2, and others scored 1 . For religion indicators, only 3 housing scored 2 for mosque, and only 2 score 3 for surau, and others score 1 . For safety indicators, all the housing scored 1. For public transportation indicators, all housing scored 1 , while train station and bus terminal only scored 1 . Housing scored 2 for bus terminal. The score shows that most of these housing areas have low scores, especially in safety indicators.

This matter can be improved by the Ministry of Housing and Local Government (KPKT). They should be aware that there are more affordable housing that is not sustainable in terms of social aspect. The highest score achieved by Pangsapuri Laksamana Jaya and Pangsapuri Ria, which both achieved only $40.15 \%$ each of sustainability level.
The lowest score with $27.47 \%$ achieved by four (4) types of affordable housing, they are Fiona apartment, PPR Gombak Setia, Pangsapuri Taman Samudera, and PR1MA Kajang Utama. Figure 1 shows the distribution of affordable housing with level of sustainability in terms of social aspects in this study.

However, there are some limitations in this study. The first one is, the spatial data used is from year 2017, and new development after 2017 was not listed and located in this study. The second limitation is in term of indicators and sub-indicators used in this study. Additional indicators and sub-indicators can be included in future to improve current assessment model. The third one is, this study only focus on affordable housing in term of high-rise affordable housing. An improvement with other housing type can be included such as landed housing.

Besides that, this study only focuses on social aspect of sustainability. Environmental and economic aspects can be included in future studies.

\subsection{CONCLUSION}

This study focuses on assessing the sustainability level in terms of social aspect for affordable housing in Malaysia. The results show that most of the affordable housing in study area did not achieve the sustainability level in term of social aspect. However, this study may facilitate stakeholders related with affordable housing, especially the Ministry of Housing and

Local Government (KPKT) to take an action towards achieving the goals of providing sustainable housing for Malaysians.

There were some issues with sustainable housing development in Malaysia, which need to be integrated with affordable housing development. Hence, there is a need to study the current practices of sustainability, affordable housing development, and enhancement of current practices need to be made. 


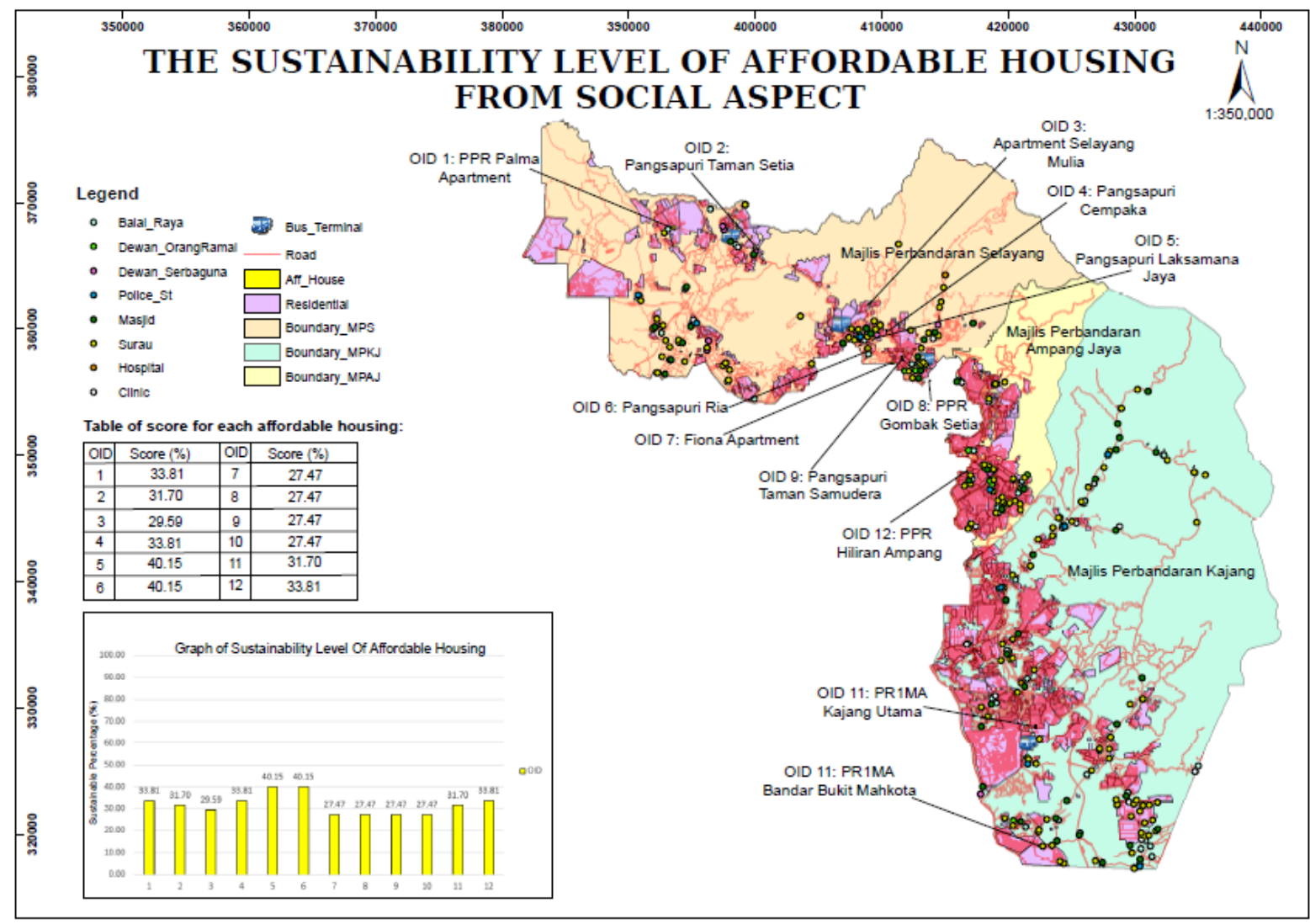

Figure 1: The sustainability level of affordable housing from social aspect in Selayang, Gombak and Kajang area.

\section{ACKNOWLEDGEMENTS}

Authors would like to thank PLANMalaysia for providing the datas. We also would like to express our gratitude to Universiti Teknologi Malaysia for funding this project under the Universiti Teknologi Malaysia, UTM Grant, GUP (Tier 1), and vote number $20 \mathrm{H} 19$

\section{REFERENCES}

Aziz, W. N. A. W. A., Hanif, N. R., \& Singaravello, K. a/l. (2011). A Study on Affordable Housing Within the Middle Income Households in the Major Cities and Towns in Malaysia. Australian Journal of Basic \& Applied Sciences. https://doi.org/10.1039/b102093p J. 1999. Road Safety Through Video Detection. Intelligent Transportation System, 1999, Proceedings 1999 IEEE/IEEJ/JSAI International Conference. 753757.

Golubchikov, O., \& Badyina, A. (2012). Sustainable housing for sustainable cities: a policy framework for developing countries. Retrieved from https://www.researchgate.net/publication/256042905_Sustainable Housing_for_Sustainable_Cities_A_Policy_Framework_for_Devel oping_Countries

JPBD. (2011). MURNInets@ | Malaysian Urban Rural National Indicators Network on Sustainable Development. Retrieved November 18, 2018, from http://murninet.townplan.gov.my/murninetsv2/page/dimensi-temadan-penunjuk-murninets-20
Karuppannan, S., \& Sivam, A. (2009). Sustainable Development and Housing Affordability

Kewangan, K. (2018). Belanjawan 2019. Retrieved from http://www.treasury.gov.my/pdf/ucapan/ub19.pdf

KPKT. (2011). Dasar Perumahan Negara. Malaysia.

KPKT. (2012). Pelan Tindakan Dasar Perumahan Negara. Malaysia.

LPPKN. (2016). Laporan Indeks Kesejahteraan Keluarga Malaysia 2016. Kertas Strategi 6: Menyediakan Perumahan Mampu Milik Yang Mencukupi Dan Berkualiti.

Mulliner, E., Smallbone, K., \& Maliene, V. (2013). An assessment of sustainable housing affordability using a multiple criteria decision making method. Omega (UnitedKingdom). https://doi.org/10.1016/j.omega.2012.05.002S.,

Nurshuhada Zainon, Faizul Azli Mohd Rahim, Syazwani Sulaiman, Saipol Bari Abd Karim, \& Atikah Hamzah. (2017). Factors Affecting the Demand of Affordable Housing among the MiddleIncome Groups in Klang Valley Malaysia. Journal of Design and Built Environment. https://doi.org/10.2307/1060496J

Oxford. (2006). Little Oxford English Dictionary. (Oxford, Ed.) (9th ed.). Oxford

Bedford, M. A. 2015. Unmanned Aircraft System (UAS) Service Demand 2015-2035. DOI : http://dx.doi.org/10.11113/jt.v79.9987 